\title{
EDITORIAL
}

\section{Can exhaled NO be used as a marker of airway inflammation?}

\author{
G. Hedenstierna, M. Högman
}

The story of endogenously produced nitric oxide (NO) began in 1980 when FurchGOTT and ZaWADSKI [1] showed that the vascular endothelium produces a powerful vaso-dilating substance which they called endothelium-derived relaxing factor (EDRF). Seven years later it was identified as NO $[2,3]$. That such a simple molecule could exert so powerful effects was met by some scepticism, but was soon a proven fact. A rapidly increasing list of publications established NO as a vasodilator, bronchodilator, neurotransmitter and an important component of the immune system [4], The detection of endogenously produced NO in expired gas by GusTAFSSON et al. [5] in 1991 was an important discovery, indicating a new way of analysing endogenously produced NO. It soon became evident that no or little NO is released from the pulmonary capillary blood into the alveolar space [6] and, thus, expired NO re-flects its production within the lung tissue itself. However, what is the cellular origin of NO and how are the different isoforms of nitric oxide synthase (NOS) activated? These questions have not yet been fully answered and more research is needed in this area.

What we do know is that the fraction of NO in exhaled gas $(F \mathrm{E}, \mathrm{NO})$ has been shown to be elevated in subjects with asthma [7], and it may reflect the severity of the disease [8]. Hence, several research groups have suggested that the noninvasive monitoring of $F$ E,NO may be a useful tool in the diagnosis of airway inflammation. It has also been suggested to be a guide in treatment with anti-inflammatory drugs, e.g. inhaled steroids, where the $F \mathrm{E}$,NO decreased with increasing dose of inhaled steroids [9]. This was considered further evidence of exhaled NO as a marker of airway inflammation. However, things seem not to be as simple as that. Firstly, asthmatics show a large range of exhaled NO concentrations and some are indistinguishable from normal subjects [10]. In this issue of the journal, $\mathrm{H}_{0}$ et al. [11] report on a larger group of asthmatics and many of these had normal concentrations of exhaled NO. This should hardly come as a surprise, since asthmatic disease may vary in intensity. Secondly, other forms of airway inflammation may not show up with increased levels of exhaled NO. It has previously been shown that the $F E$,NO in patients with cystic fibrosis is not different from that in normal controls [12-14] and the FE,NO can even be reduced [15]. Moreover, Ho et al. [11] found no variation in the FE,NO during the course of exacerbation of the airway inflammation and its treatment by antibiotics. Nor did

Dept of Medical Sciences, Clinical Physiology, University Hospital and Asthma Research Centre, Uppsala University, Uppsala, Sweden.

Correspondence: G. Hedenstierna, Dept of Clinical Physiology, University Hospital, S-751 85 Uppsala, Sweden, Fax: 4618664135 patients with bronchiectasis demonstrate increased expired NO, despite signs of active inflammation [11].

Why is an increase in exhaled NO not seen in the presence of airway inflammation? One possible explanation is lack of upregulation of inducible NOS. Support for this view was found in patients with cystic fibrosis [16]. Impaired diffusion from the inflammatory cells through debris, oedema and mucus into the airway lumen, or increased scavenging of $\mathrm{NO}$ are other, perhaps more likely, mechanisms, as discussed by $\mathrm{H}_{0}$ et al. [11]. There are also other conditions of lung tissue inflammation that do not have increased exhaled NO, as, for example, in adult respiratory distress syndrome (ARDS) [17] and airway inflammation associated with Kartagener's syndrome with immobilized airway epithelial cilia [18]. Another interesting finding is the positive correlation between exhaled NO and eosinophils in sputum [19] and eosinophil peroxidase in bronchoalveolar lavage (BAL) [20], and the negative correlation between exhaled NO and the specific neutrophil marker, human neutrophil lipocalin, in BAL [20]. The mechanisms behind these different correlations remain to be explained but they emphasize that airway inflammation and exhaled NO are exposed to much more complex relationships than might initially have been thought of.

Why have there been different findings in expired NO in some of the reports on airway disease? One likely explanation is individual variations that may have an impact on the mean result in studies on small groups of patients. The study by Ho et al. [11] has the merit of being based on relatively large number of patients. Another contrib-uting factor to different results may well be different techniques for assessing the FE,NO. The present study by $\mathrm{H}_{0}$ et al. [11] has used a respiratory manoeuvre that includes a maximum inspiration and an immediate slow expiration at a constant respiratory flow, according to the recommendations that emerged from the European Respiratory Society Task Force "Measurements of nitric oxide in exhaled air" [21]. This adds strength to the study of $\mathrm{Ho}$ et al. [11] as does the inclusion of negative controls (healthy subjects) and of positive controls (asthmatic subjects) when analysing the data from patients with cystic fibrosis and bronchiectasis, all studied by the same technique. However, there is an inverse dependence on expiratory flow rate and $F$ E,NO $[22,23]$. There is about a four-fold difference between a slow expiration at $0.05 \mathrm{~L} \cdot \mathrm{s}^{-1}$ and the recommended flow rate of $0.25 \mathrm{~L} \cdot \mathrm{s}^{-1}$ [22]. The output of NO from the airways is controlled by laws of diffusion, and at high flows, when the contact time of the alveolar or peripheral gas with the airway surface is short, the peripheral NO concentrations dominate. Thus, to demonstrate the NO output from the airway wall, low flow rates may preferably be used to allow time for diffusion. Since it has been shown 
that patients with bronchiectasis have a strong expression of inducible NOS in the bronchial epithelium [16], one would expect to find increased levels of exhaled NO. Indeed, elevated levels of NO have been found in this group of patients, when the NO measurements were carried out during a very slow vital capacity manoeuvre [24]. This points to a review of the current recommendations to measure exhaled NO. Another question that also has to be addressed is the use of the vital capacity manoeuvre itself. The manoeuvre can be tricky in severe lung disease, in children and infants and will be difficult to apply in the intensive care setting.

In summary, the analysis of exhaled nitric oxide goes through evolutionary cycles, as other interesting discoveries do. The recording of exhaled nitric oxide for the assessment of airways disease seems to be more complex than initially thought. However, ongoing research increases our insight into the mechanisms of exhaled nitric oxide. It is obvious that before having full control over the technique as a diagnostic procedure, it must be known from which lung regions and from which cells the nitric oxide comes and which mechanisms can impede the output of nitric oxide via the airways. With this knowledge it may be possible to use the recording of exhaled nitric oxide as a more exact diagnostic tool for the assessment of airways disease. A noninvasive, fast and simple to perform test may then become reality.

\section{References}

1. Furchgott RF, Zawadski JV. The obligatory role of endothelial cells in the relaxation of arterial smooth muscle by acetylcholine. Nature 1980; 288: 373-376.

2. Palmer RMJ, Ferrige AG, Moncada S. Nitric oxide release accounts for the biological activity of endotheliumderived relaxing factor. Nature 1987; 327: 524-526.

3. Ignarro LJ, Buga GM, Wood KS, Byrns RE, Chaudhuri G. Endothelium derived relaxing factor produced and released from artery and vein in nitric oxide. Proc Natl Acad Sci USA 1987; 84: 9265-9269.

4. Moneada S, Palmer RM, Higgs EA. Nitric oxide: physiology, pathophysiology, and pharmacology. Pharmacol Rev 1991; 43: 109-142.

5. Gustafsson LE, Leone A, Persson M, Wiklund N, Moncada $\mathrm{S}$. Endogenous nitric oxide is present in the exhaled air of rabbits, guinea pigs and humans. Biochem Biophys Res Commun 1991; 181: 852-857.

6. Cremona G, Higenbottam. T, Takao M, Hall L, Bower EA. Exhaled nitric oxide in isolated pig lungs. J Appl Physiol 1995; 78: 59-63.

7. Alving K, Weimberg E, Lundberg JM. Increased amount of nitric oxide in exhaled air of asthmatics. Eur Respir $J$ 1993; 6: 1368-1370.

8. Massaro AF, Gaston B, Kita D, Fanta C, Stamler JS, Drazen JM. Expired nitric oxide levels during treatment of acute asthma. Am J Respir Crit Care Med 1995; 152: 800803.
9. Kharitonov SA, Yates DH, Chung KF, Barnes PJ. Changes in the dose of inhaled steroid affect exhaled nitric oxide levels in asthmatic patients. Eur Respir J 1996; 9: 196201.

10. Högman M, Anderson SD, Lúdviksdóttir D, Björnsson E, Chan $\mathrm{H}$, Hedenström H. Exhaled NO decreases due to hyperosmolar challenge in subjects with symptoms of asthma. Eur Respir J 1997; 10: 10s.

11. Ho LP, Innes JA, Greening AP. Exhaled nitric oxide is not elevated in the inflammatory airways diseases of cystic fibrosis and bronchiectasis. Eur Respir J 1998; 12: 12901294.

12. Lundberg JO, Nordvall SL, Weitzberg E, Kollberg H, Alving K. Exhaled nitric oxide in paediatric asthma and in cystic fibrosis. Arch Dis Child 1996; 75: 323-326.

13. Lundberg JO, Weitzberg E, Lundberg JM, Alving K. Nitric oxide in exhaled air. Eur Respir J 1996; 9: 2671-2680.

14. Dótsch J, Demiranca S, Terbrook HG, Huls G, Rascher W, Kuhl PG. Airway nitric oxide in asthmatic children and patients with cystic fibrosis. Eur Respir J 1996; 9: 2537-2540.

15. Balfour-Lynn IM, Laverty A, Dinwiddie R. Reduced upper airway nitric oxide in cystic fibrosis. Arch Dis Child 1996; 75: 319-322.

16. Meng QH, Springall DR, Bishop AE, et al. Lack of inducible nitric oxide synthase in bronchial epithelium: a possible mechanism of susceptibility to infection in cystic fibrosis. J Pathol 1998; 184: 323-331.

17. Brett SJ, Evans TW. Measurement of endogenous nitric oxide in the lungs of patients with the acute respiratory distress syndrome. Am J Respir Crit Care Med 1998; 157: 993-997.

18. Lundberg JON, Weitzberg E, Nordvall SL, Kuylenstierna $\mathrm{R}$, Lundberg JM, Alving K. Primarily nasal origin of exhaled nitric oxide and absence in Kartagener's syndrome. Eur Respir J 1994; 7: 1501-1504.

19. Jatakanon A, Lim S, Kharitonov SA, Chung KF, Barnes PJ. Correlation between exhaled nitric oxide, sputum eosinophils, and methacholine responsiveness in patients with mild asthma. Thorax 1998; 53: 91-95.

20. Venge P, Högman M, Lúdviksdóttir D, Boman G. Exhaled NO. The impact of the activation of eosinophils and neutrophils in the airways. Am J Respir Crit Care Med 1998; 157: A598.

21. Kharitonov SA, Alving K, Barnes PJ. Exhaled and nasal nitric oxide measurements: recommendations. Eur Respir J 1997; 10: 1683-1693.

22. Högman M, Strömberg S, Schedin U, Frostell C, Hedenstierna G, Gustafsson LE. Nitric oxide from the human respiratory tract efficiently quantified by standardized single breath measurements. Acta Physiol Scand 1997; 159: 345-346.

23. Silkoff PE, McClean PA, Slutsky AS, et al. Marked flow-dependence of exhaled nitric oxide using a new technique to exclude nasal nitric oxide. Am J Respir Crit Care Med 1997; 155: 260-267.

24. Kharitonov SA, Wells AU, O'Conner BJ. Elevated levels of exhaled nitric oxide in bronchiectasis. Am J Respir Crit Care Med 1995; 151: 1889-1893. 